\title{
EFFECT OF ENDOTOXIC SHOCK ON RENAL AND HORMONAL FUNCTIONS
}

\author{
T. Oyama, K. Toyooka, Y. Sato, S. Kondo, and T. Kudo
}

IN A PREVIous STUDY ${ }^{1}$ we reported the influence of haemorrhagic shock on canine endocrine function and we found that the haemorrhagic hypotension was associated with greatly increased plasma concentrations of catecholamines and anti-diuretic hormone (ADH). Furthermore, we elucidated that the main beneficial role of steroids on haemorrhagic shock was attributable to their depressive effect on these vaso-active hormones. In the present study the effect of endotoxic shock on endocrine and renal functions was investigated in dogs, and the mechanism of the anti-shock effects of corticosteroid in endotoxic shock was also explored. Plasma concentrations of ADH, epinephrine, norepinephrine, aldosterone, renin activity, cortisol and insulin were measured simultaneously during and following endotoxic shock. Other parameters such as renal tissue blood flow, cardiac output, urine volume and osmolality, serum and urine electrolytes, blood pyruvic and lactic acid and blood glucose were also analyzed simultaneously during the procedure.

\section{Materials and Methods}

Forty-four mongrel dogs weighing seven to fifteen kilograms were divided into three groups: (1) Group One: Iwenty dogs not pretreated with steroid and subjected to endotoxic shock. These were further divided into two sub-groups: (A) Five dogs in which plasma concentrations of epinephrine and nor-epinephrine were determined. (B) Fifteen dogs in which plasma concentrations of ADH, aldosterone, renin activity, cortisol, insulin and other parameters, which have been described above, were determined. (2) Group Two: twelve dogs pretreated with methylprednisolone sodium succinate $30 \mathrm{mg} / \mathrm{kg}$ body weight. (3) Group Three: twelve dogs pretreated with dexamethasone sodium sulfate $5 \mathrm{mg} / \mathrm{kg}$.

Dogs in all three groups were anaesthetized with intravenous pentobarbitone $30 \mathrm{mg} / \mathrm{kg}$ body

T. Oyama, M.D., Professor and Chairman; K. Toyooka, B.S., Y. Sato, B.S., S. Kondo, B.S., and T. Kudo, M.D., Department of Anaesthesia, Hirosaki University School of Medicine, Hirosaki, Aomori-ken, Japan. weight, followed by tracheal intubation. Ventilation was controlled with an AIKA ventilator on room air, set at a tidal volume of $15 \mathrm{ml} / \mathrm{kg}$ body weight and a respiratory rate 12 per minute to maintain the $\mathrm{Pa}_{\mathrm{CO}_{2}}$ at 4.66 to $5.32 \mathrm{kPa}$ ( 35 to $40 \mathrm{~mm}$ $\mathrm{Hg}$ ). A catheter was inserted into the right femoral artery to measure arterial blood pressure and to permit blood sampling. The left femoral vein was used for administration of fluids and drugs.

Special needle electrodes* were inserted into the left renal cortex and medulla following the method described by Leighton, et al. ${ }^{2}$ Renal tissue blood flow just before the administration of endotoxin was defined as 100 per cent and that one hour after the animal had been sacrificed was considered to be 0 per cent.

After obtaining the control blood sample, each animal was injected over a period of five minutes with a fatal intravenous dose of E. coli (Difco) 3 mg per kilogram body weight. Lactated Ringer's solution $6 \mathrm{ml} / \mathrm{kg} / \mathrm{hr}$ was given throughout the procedure to all three groups. Methylprednisolone $15 \mathrm{mg} / \mathrm{kg}$ or dexamethasone $5 \mathrm{mg} / \mathrm{kg}$ was administered intravenously just prior to the administration of endotoxin, but only the first blood sample for groups two and three had been drawn. Measurements were made at the following times after the control sampling: (1) 30 minutes after the injection of endotoxin, (2) one and two hours after the administration of endotoxin as shown in Figure 1.

ADH was measured on $2 \mathrm{ml}$ of plasma by the radioimmunoassay method of Husain, et al. ${ }^{3}$ Catecholamine concentration was determined on $10 \mathrm{ml}$ of plasma according to the method of Griffith, et al. ${ }^{4}$ using trihydroxyindol with spectrofluorimetry. Aldosterone concentration was obtained from $0.5 \mathrm{ml}$ of plasma according to the method of Mackenzie. 5 Plasma renin activity was measured according to the method of Haber, and the plasma insulin concentration was determined by the method of Morgan and Lazarow. ${ }^{6}$ The recovery rate for plasma renin activity was 74 per cent and the coefficient of variation was 7.5 per cent. The recovery rate for plasma insulin

\footnotetext{
*Manufactured by Sanei Socci Co. Ltd.
} 


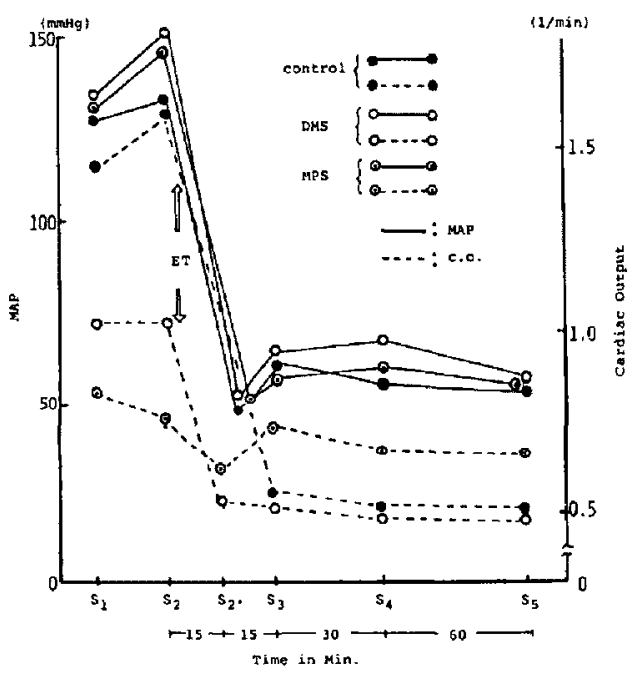

Figure 1. Effects of endotoxin shock and steroid on mean arterial pressure (MAP) and cardiac output (CO) in dogs.

was 94 per cent. The details of analysis of the above hormones have been described by us previously.'

Plasma concentration of cortisol was analyzed in $0.5 \mathrm{ml}$ of plasma according to the method of Rudd, et al. ${ }^{7}$ Plasma levels of lactate and pyruvate were determined by enzymatic assay according to the method of Authoy, et al. ${ }^{\mathrm{a}}$ The cardiac output was measured by the thermodilution method with a cardiovascular instrument's apparatus through a Swan-Ganz catheter. Student's t-test was used for the statistical analysis.

\section{Results}

\section{Plasma Anti-Diuretic Hormone ( $A D H$ )}

Plasma $A D H$ levels increased to about twice the control values after the peritoneal incision and they increased significantly 20 and 25 times ( $P$ $<0,01) 15$ and 30 minutes after the administration of endotoxin, respectively. They decreased gradually later, but there remained still a 15-fold elevation two hours post-endotoxin in control group one as shown in Table I and Figure 2. In groups two and three plasma ADH rose 15- to 20-fold compared with controls $\mathbf{3 0}$ minutes after endotoxin administration as shown in Table $I$ and Figure 3. However, the values at corresponding post-endotoxin times were lower than those of the control group and the difference is statistically significant (Table I).

\section{Plasma epinephrine and norepinephrine}

In Group One, plasma epinephrine, and norepinephrine concentrations increased significantly to 21 times and four times control level respectively 30 minutes after the administration of endotoxin. Thereafter plasma epinephrine levels remained at these same high levels as shown in Table $I$ and Figure 2. Plasma norepinephrine concentration reached a peak of five times control level two hours after the administration of endotoxin.

\section{Plasma atdosterone and renin activity}

Plasma aldosterone levels and renin activity increased significantly to about four times and twice control levels respectively 30 minutes after the administration of endotoxin. They stayed at these levels thereafter in group one as shown in Table I and Figure 4. In groups two and three a similar tendency was observed in plasma concentrations of aldosterone, and this is shown in Table I and Figure 4. However, pretreatment with methylprednisolone or dexamethasone decreased renin activity significantly as compared with animals in the non-steroid treated control group one (Table I and Figure 5).

\section{Plasma cortisol and insulin}

Plasma cortisol levels increased significantly with shock in all three groups as shown in Table I and Figure 6. They rose, for instance, to 3 times control level 30 minutes after the administration of endotoxin, and thereafter continued at this level (Figure 6). In groups two and three the mere administration of methylprednisolone or dexamethasone increased the plasma concentration of cortisol. Plasma insulin concentration increased significantly to about five times control level 30 minutes after the injection of endotoxin, but thereafter it decreased gradually as shown in Figure 7 .

\section{Renal tissue blood flow}

Renal cortical tissue blood flow decreased to the lowest level, about 39 to 42 per cent of control value, 15 minutes post-endotoxin in all three groups; thereafter it improved slightly as demonstrated in Figure 8 and Table II. However, no significant differences were observed among three groups. It improved a little to 66 and 42 per cent of control one and two hours postendotoxin.

Renal medullary tissue blood flow decreased significantly to 46 to 53 per cent of control level 15 minutes post-endotoxin in all groups. It improved 
TABLE I

Effect of Endotoxin and administration of Steroids on Plasma Concentrations of ADH, PRA, Aldosterone, ACTH, Cortisol, Epinephrine, Norepinephrine and Insulin in Dogs

\begin{tabular}{|c|c|c|c|c|c|c|c|c|}
\hline \multirow[b]{2}{*}{ Parameter } & \multirow[b]{2}{*}{ Group } & \multirow[b]{2}{*}{$\mathbf{N}$} & \multirow[b]{2}{*}{ Pre Et } & \multicolumn{5}{|c|}{ (Minutes after Et) } \\
\hline & & & & 0 & 15 & 30 & 60 & 120 \\
\hline $\begin{array}{l}\text { ADH } \\
\qquad(\mu \mathrm{U} / \mathrm{ml})\end{array}$ & $\begin{array}{l}\text { Control } \\
\text { DMS } \\
\text { MPS }\end{array}$ & 15 & $\begin{array}{r}4.0 \\
\pm 1.1 \\
2.5 \\
\pm 0.4 \\
2.2 \\
\pm 0.3\end{array}$ & $\begin{array}{r}7.8 \\
\pm 2.5 \\
10.6 \\
\pm 2.9 \\
12.1 \\
\pm 3.5\end{array}$ & $\begin{aligned} & 83.4^{*} \\
& \pm 12.8 \\
& 51.3^{*} \\
& \pm 12.3 \\
& 19.6^{*} \\
& \pm 2.8\end{aligned}$ & $\begin{array}{c}104.3^{*} \\
\pm 16.8 \\
53.9^{*} \\
\pm 9.6 \\
35.6^{*} \\
\pm 6.9\end{array}$ & $\begin{aligned} & 86.5^{*} \\
& \pm 11.8 \\
& 50.3^{*} \\
& \pm 10.9 \\
& 36.3^{*} \\
& \pm 6.8\end{aligned}$ & $\begin{array}{c}61.2^{*} \\
\pm 9.9 \\
36.8^{*} \\
\pm 12.4 \\
23.0^{*} \\
\pm 2.3\end{array}$ \\
\hline $\begin{array}{l}\text { PRA } \\
\quad(\mathrm{ng} / \mathrm{ml} / \mathrm{hr})\end{array}$ & $\begin{array}{l}\text { Control } \\
\text { DMS } \\
\text { MPS }\end{array}$ & 15 & $\begin{array}{r}4.6 \\
\pm 0.5 \\
3.0 \\
\pm 0.4 \\
4.4 \\
\pm 0.3\end{array}$ & $\begin{array}{r}3.8 \\
\pm 0.5 \\
3.6 \\
\pm 0.7 \\
4.8 \\
\pm 0.5\end{array}$ & $\begin{array}{l}- \\
- \\
- \\
-\end{array}$ & $\begin{array}{r}7.1 \\
\pm 0.6 \\
4.9^{*} \\
\pm 0.2 \\
5.5 \\
\pm 0.6\end{array}$ & $\begin{aligned} & 9.6^{*} \\
& \pm 1.1 \\
& 5.5^{*} \\
& \pm 0.5^{\circ} \\
& 6.9^{*} \\
& \pm 0.7\end{aligned}$ & $\begin{aligned} & 8.8^{*} \\
\pm & 0.8 \\
& 6.5^{*} \\
\pm & 0.5 \\
& 6.5^{*} \\
\pm & 0.9\end{aligned}$ \\
\hline $\begin{array}{l}\text { Aldosterone } \\
(\mathrm{ng} / 100 \mathrm{ml})\end{array}$ & $\begin{array}{l}\text { Control } \\
\text { DMS } \\
\text { MPS }\end{array}$ & $\begin{array}{l}15 \\
12\end{array}$ & $\begin{array}{r}14.6 \\
\pm 1.6 \\
16.9 \\
\pm 1.9 \\
17.7 \\
\pm 2.0\end{array}$ & $\begin{array}{c}17.7 \\
\pm 2.4 \\
25.7 \\
\pm 3.8 \\
32.6^{*} \\
\pm 5.6\end{array}$ & $\begin{array}{l}- \\
- \\
- \\
-\end{array}$ & $\begin{array}{c}56.5^{*} \\
\pm 6.5 \\
63.1^{*} \\
\pm 4.4^{*} \\
60.3^{*} \\
\pm 10.9\end{array}$ & $\begin{array}{c}55.9^{*} \\
\pm 6.1 \\
65.9^{*} \\
\pm 9.7 \\
57.0^{*} \\
\pm 8.0\end{array}$ & $\begin{array}{c}58.8^{*} \\
\pm 6.2 \\
81.4^{*} \\
\pm 10.2 \\
61.1^{*} \\
\pm 7.1\end{array}$ \\
\hline $\begin{array}{l}\text { ACTH } \\
(\mathrm{pg} / \mathrm{ml})\end{array}$ & $\begin{array}{l}\text { Control } \\
\text { MPS }\end{array}$ & 4 & $\begin{array}{r}64.8 \\
+5.1 \\
71.7 \\
\pm 15.3\end{array}$ & $\begin{array}{l}182.3^{*} \\
\pm 18.3^{3} \\
138.3^{*} \\
\pm 11.1\end{array}$ & $\begin{array}{c}316.9^{*} \\
\pm 38.1 \\
243.3^{*} \\
\pm 76.5\end{array}$ & $\begin{array}{c}315.8^{*} \\
\pm 13.9 \\
238.3^{*} \\
\pm 55.3\end{array}$ & $\begin{array}{c}328.8^{*} \\
\pm 69.6 \\
233.3^{*} \\
\pm 51.2\end{array}$ & $\begin{array}{l}- \\
- \\
-\end{array}$ \\
\hline $\begin{array}{l}\text { Cortisol } \\
\qquad(\mu \mathrm{g} / 100 \mathrm{ml})\end{array}$ & $\begin{array}{l}\text { Control } \\
\text { DMS } \\
\text { MPS }\end{array}$ & 15 & $\begin{array}{r}7.9 \\
\pm 0.7 \\
7.9 \\
\pm 0.6 \\
10.5 \\
+1.2\end{array}$ & $\begin{array}{c}14.4^{*} \\
\pm 0.7 \\
15.0^{*} \\
\pm 1.4 \\
23.4^{*} \\
\pm 2.5\end{array}$ & $\begin{array}{l}- \\
- \\
- \\
-\end{array}$ & $\begin{array}{c}23.3^{*} \\
\pm 1.4 \\
24.1^{*} \\
\pm 1.5 \\
31.0^{*} \\
\pm 2.3\end{array}$ & $\begin{array}{c}22.8^{*} \\
\pm 1.7 \\
27.0^{*} \\
\pm 1.9 \\
30.4^{*} \\
\pm 2.0\end{array}$ & $\begin{array}{c}26.1^{*} \\
\pm 1.7 \\
29.8^{*} \\
\pm 2.8 \\
32.1^{*} \\
\pm 2.5\end{array}$ \\
\hline $\begin{array}{l}\text { Epinephrine } \\
(\mu \mathrm{g} / \mathrm{l})\end{array}$ & & 5 & $\begin{array}{r}1.32 \\
\pm 0.25\end{array}$ & $\begin{array}{r}1.68 \\
\pm 0.44\end{array}$ & - & $\begin{array}{r}28.39 \\
\pm 9.21^{*}\end{array}$ & $\begin{array}{r}16.02 \\
\pm 3.43 \dagger\end{array}$ & $\begin{array}{l}23.81 \\
\pm 6.93^{*}\end{array}$ \\
\hline $\begin{array}{l}\text { Norepinephrine } \\
(\mu \mathrm{g} / \mathrm{l})\end{array}$ & & 5 & $\begin{array}{r}0.32 \\
\pm 0.11\end{array}$ & $\begin{array}{r}0.31 \\
\pm 0.06\end{array}$ & - & $\begin{array}{c}1.43 \\
\pm 0.35^{*}\end{array}$ & $\begin{array}{c}1.52 \\
\pm 0.43^{*}\end{array}$ & $\begin{array}{c}1.78 \\
\pm 0.43^{*}\end{array}$ \\
\hline $\begin{array}{l}\text { Insulin } \\
\qquad(\mu \mathrm{U} / \mathrm{ml})\end{array}$ & & 5 & $\begin{array}{r}14.3 \\
\pm 2.7\end{array}$ & $\begin{array}{r}18.1 \\
\pm 3.7\end{array}$ & - & $\begin{array}{c}72.7 \\
\pm 11.6 \dagger\end{array}$ & $\begin{aligned} & 51.0 \\
\pm & 14.8^{*}\end{aligned}$ & $\begin{array}{r}35.8 \\
\pm 11.6\end{array}$ \\
\hline
\end{tabular}

"Statistically significant as compared with control value $[(P<0.05)$ Pre. Et].

† Statistically significant compared with control $(P<0.01), E t=$ administration of Endotoxin, each value represents a mean \pm S.E., DMS: dexamethazone $(5 \mathrm{mg} / \mathrm{kg})$ administered intravenously, MPS: methylprednisolone $(30 \mathrm{mg} / \mathrm{kg})$ administered intravenously, ADH : antidiuretic hormone, PRA: plasma renin activity, ACTH: adrenocorticotropic hormone.

to 63 to 65 per cent and 61 to 64 per cent one and two hours post-endotoxin respectively in the steroid treated groups (Table II and Figure 8).

\section{Urine volume, osmolality and electrolytes}

Urine output decreased markedly during shock, in that it fell to 70 per cent and to 8 per cent of control levels 30 minutes and two hours after the administration of endotoxin in group one, as shown in Table III. Pre-administration of methylprednisolone was apparently effective to improve urinary output, which fell to 28 per cent of control values two hours post-endotoxin.

Urine osmolality decreased significantly to 45 per cent of control values two hours postendotoxin.

Urine sodium concentration decreased progressively during the procedure, and urine potassium concentration had decreased by 30 per cent two hours post-endotoxin. No appreciable effect on urine osmolality or electrolytes was detected in the steroid pretreated groups two and three. 


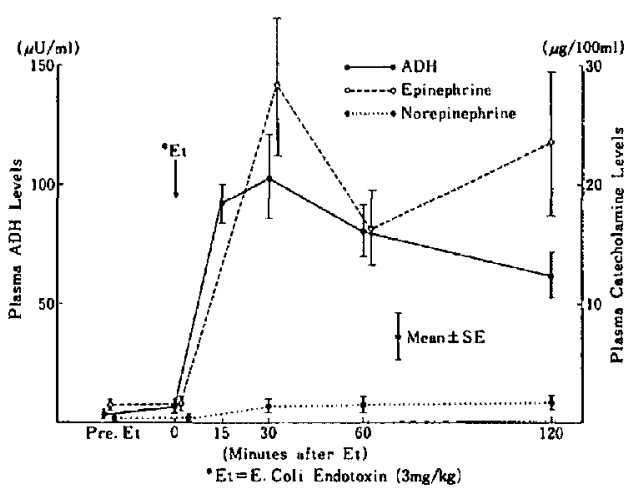

FIGURE 2. Effects of endotoxin shock on plasma ADH and catecholamine levels in dogs.

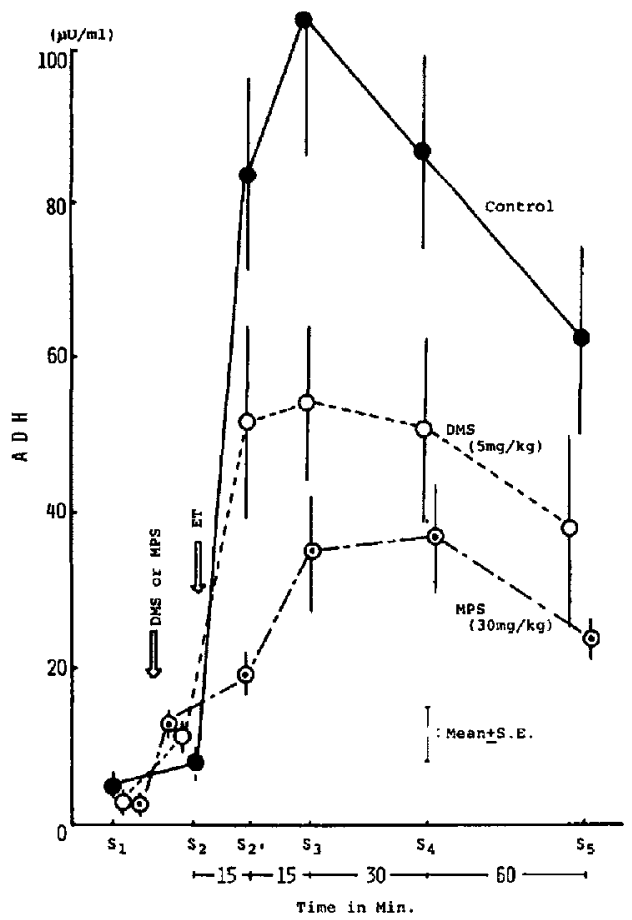

Figure 3. Plasma antidiuretic hormone levels during endotoxin shock.

\section{Serum osmolality and electrolytes}

Serum osmolality had risen slightly by 1.5 per cent one hour post-endotoxin in all three groups. It had increased significantly to four per cent two hours post-endotoxin in the control group, while in the steroid treated groups values were lower than controls.

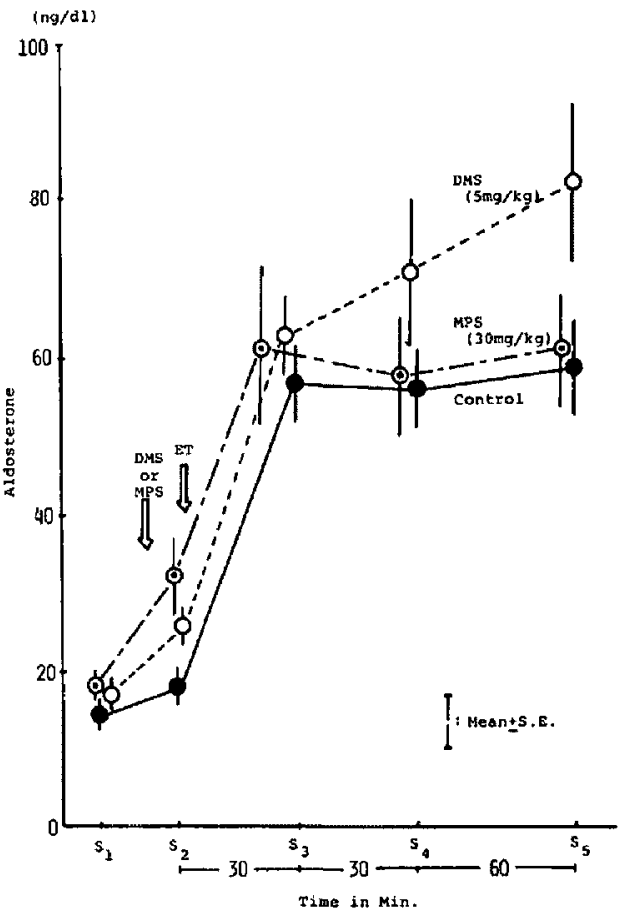

Figure 4. Plasma aldosterone levels during endotoxin shock.

Plasma sodium concentration decreased slightly in all groups.

Plasma potassium concentration had increased significantly at 15 minutes and had decreased significantly one and two hours postendotoxin. However, in the dexamethasone treated group three, potassium concentration decreased significantly by 15 to 20 per cent compared with the control group one hour postendotoxin (Table IV).

\section{Blood gases and $\mathrm{pH}$}

Blood $p H$ and base excess decreased significantly after the administration of endotoxin, but no appreciable change was observed in $\mathrm{Pa}_{2}$ or $\mathrm{Pa}_{\mathrm{CO}_{2}}$ in group one as demonstrated in Table $V$. In groups two and three blood $\mathrm{H}^{+}$was 2 to 5 $\mathrm{nmol} / \mathrm{l}$ lower ( $\mathrm{pH} 0.02-0.05$ higher) than that of the control group two hours post-endotoxin. No significant effect of steroid administration on base excess was detected.

\section{Mean arterial blood pressure and cardiac out- put}

Mean arterial blood pressure decreased mark- 


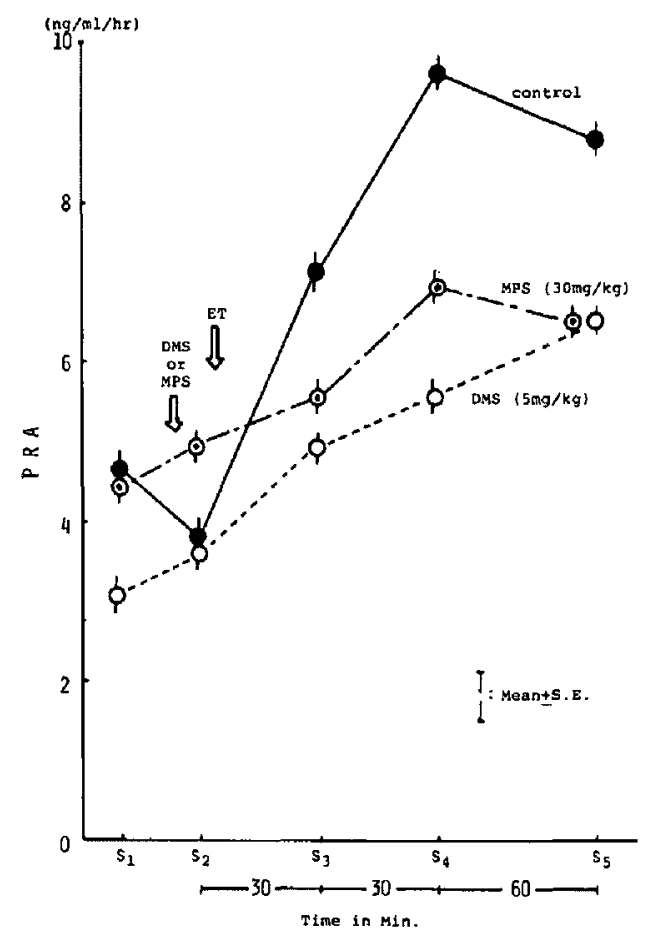

FIgURE 5. Plasma renin activity during endotoxin shock.

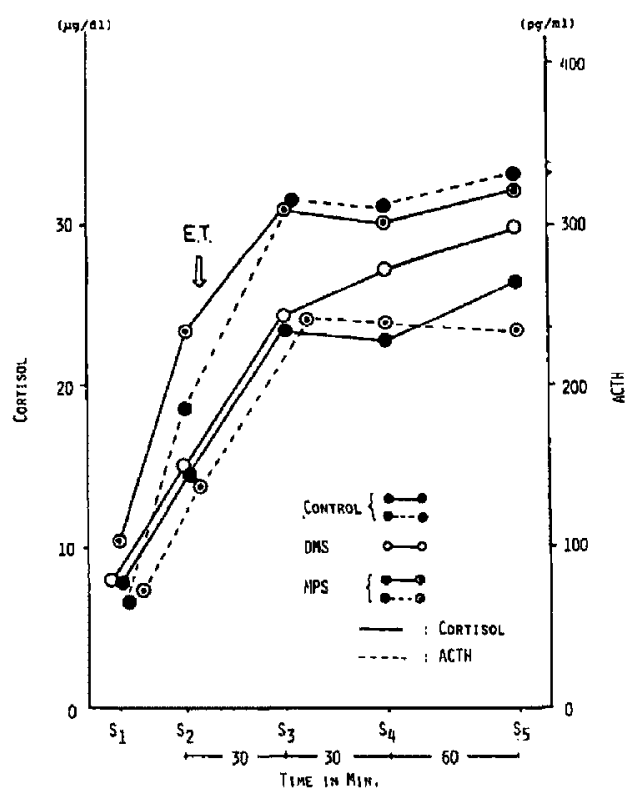

Figure 6. Effects of endotoxin shock and steroid on plasma cortisol ACTH levels in dogs.

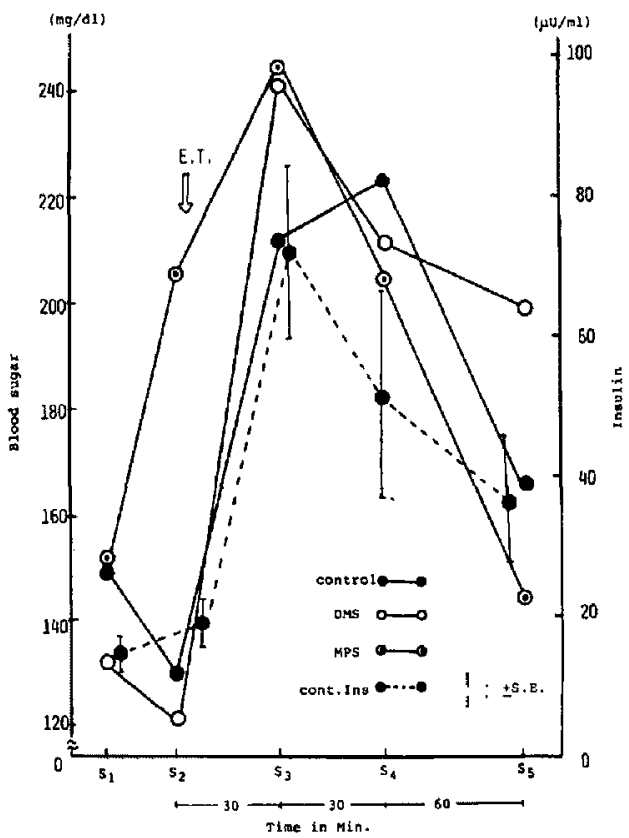

Figure 7. Effects of endotoxin shock and steroid on blood sugar and insulin levels in dogs.

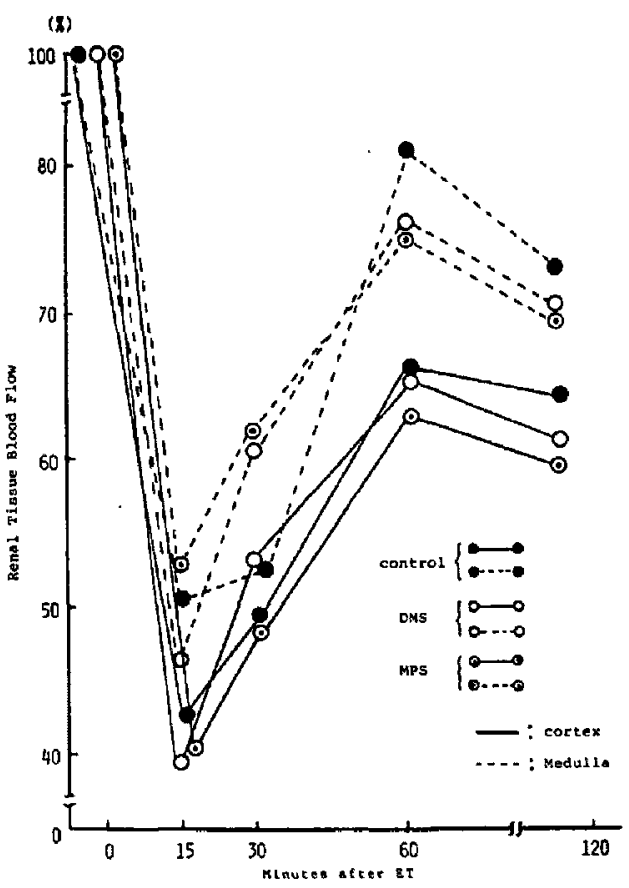

FIGURE 8. Effects of endotoxin shock and steroid on renal tissue blood flow in dogs. 
TABLE II

Effects of Dexamethasone and Methylprednisolone on Mean Arterial Blood Pressuke (Map), Cardiac Output (C.O.), Renal Tissue Blood Flow (RBF), Plasma lactate and Pyruvate levels in Dogs

\begin{tabular}{|c|c|c|c|c|c|c|c|c|}
\hline \multirow[b]{2}{*}{ Data } & \multirow[b]{2}{*}{ Group } & \multirow[b]{2}{*}{$N$} & \multirow[b]{2}{*}{ Pre Et } & \multicolumn{5}{|c|}{ (Minutes after $\mathrm{Et}$ ) } \\
\hline & & & & 0 & 15 & 30 & 60 & 120 \\
\hline $\begin{array}{l}\text { MABP } \\
\quad(\mathrm{mm} \mathrm{Hg})\end{array}$ & $\begin{array}{l}\text { Control } \\
\text { DMS } \\
\text { MPS }\end{array}$ & $\begin{array}{l}15 \\
12 \\
12\end{array}$ & $\begin{array}{r}134.3 \\
\pm 4.6 \\
239.5 \\
\pm 6.6 \\
131.1 \\
\pm 5.2\end{array}$ & $\begin{array}{r}152.6 \\
\pm 3.2 \\
134.2 \\
\pm 7.4 \\
148.1 \\
\pm 5.3\end{array}$ & $\begin{array}{c}52.1^{*} \\
\pm 4.9 \\
49.7^{*} \\
\pm 6.0^{\circ} \\
51.2^{*} \\
\pm 5.0\end{array}$ & $\begin{array}{c}63.3^{*} \\
\pm 8.2^{*} \\
60.1^{*} \\
\pm 8.1 \\
59.8^{*} \\
\pm 6.3\end{array}$ & $\begin{array}{c}66.1^{*} \\
\pm 7.6 \\
56.0^{*} \\
\pm 5.4 \\
58.1^{*} \\
\pm 5.1\end{array}$ & $\begin{array}{c}56.0^{*} \\
\pm 4.9 \\
56.5^{*} \\
\pm 6.5 \\
55.6^{*} \\
\pm 6.5\end{array}$ \\
\hline $\begin{array}{l}\text { C.O. } \\
(L / M)\end{array}$ & $\begin{array}{l}\text { Control } \\
\text { DMS } \\
\text { MPS }\end{array}$ & $\begin{array}{l}15 \\
12 \\
12\end{array}$ & $\begin{array}{r}1.44 \\
\pm 0.08 \\
1.08 \\
\pm 0.07 \\
0.83^{*} \\
\pm 0.14\end{array}$ & $\begin{array}{r}1.60 \\
\pm 0.15 \\
1.18 \\
\pm 0.10 \\
0.77^{*} \\
\pm 0.13\end{array}$ & $\begin{array}{c}- \\
- \\
0.52^{*} \\
\pm 0.02 \\
0.61^{*} \\
\pm 0.08\end{array}$ & $\begin{array}{rl} & 0.55^{*} \\
\pm & 0.06 \\
0.50^{*} & 0.04 \\
\pm & 0.04 \\
0.73^{*} \\
\pm & 0.09\end{array}$ & $\begin{array}{c}0.50^{*} \\
\pm 0.04 \\
0.49^{*} \\
\pm 0.07 \\
0.67^{*} \\
\pm 0.02\end{array}$ & $\begin{array}{c}0.50^{*} \\
\pm 0.08 \\
0.50^{*} \\
\pm 0.04 \\
0.67^{*} \\
\pm 0.10\end{array}$ \\
\hline RBF $(\%)$ Cortex & $\begin{array}{l}\text { Control } \\
\text { DMS } \\
\text { MPS } \\
\text { Control } \\
\text { DMS } \\
\text { MPS }\end{array}$ & $\begin{array}{l}15 \\
12 \\
12 \\
15 \\
12 \\
12\end{array}$ & & $\begin{array}{l}100 \\
100 \\
100 \\
100 \\
100 \\
100\end{array}$ & $\begin{array}{c}42.6 \dagger \\
\pm 5.5 \\
39.2 \dagger \\
\pm 4.0 \\
40.3 \dagger \\
\pm 4.6 \\
50.3 \dagger \\
\pm 6.8 \\
46.6 \dagger \\
\pm 5.9 \\
53.1 \dagger \\
\pm 5.2\end{array}$ & $\begin{array}{c}49.3 \dagger \\
\pm 6.4 \\
53.2 \dagger \\
\pm 7.8 \\
48.7 \dagger \\
\pm 8.3 \\
53.6 \dagger \\
\pm 0.5 \\
60.2 \dagger \\
\pm 8.8 \\
62.1 \dagger \\
\pm 10.3\end{array}$ & $\begin{array}{r}66.3 \\
+10.6 \\
65.4 \\
\pm 8.6 \\
63.2 \\
\pm 9.9 \\
81.2 \\
\pm 9.5 \\
76.8 \\
\pm 10.3 \\
75.4 \\
+8.8\end{array}$ & $\begin{array}{r}64.5 \\
\pm 8.9 \\
61.4 \\
\pm 9.6 \\
59.9 \\
\pm 7.9 \\
73.2 \\
\pm 7.8 \\
70.8 \\
\pm 6.4 \\
69.4 \\
\pm 8.2\end{array}$ \\
\hline $\begin{array}{l}\text { Blood sugar level } \\
\quad(\mathrm{mg} / \mathrm{dl})\end{array}$ & $\begin{array}{l}\text { Control } \\
\text { DMS } \\
\text { MPS }\end{array}$ & $\begin{array}{l}15 \\
12 \\
12\end{array}$ & $\begin{array}{r}150.0 \\
\pm 13.8 \\
132.7 \\
\pm 7.7 \\
151.8 \\
\pm 6.6\end{array}$ & $\begin{array}{c}128.3 \\
\pm 11.6 \\
120.5 \\
\pm 11.2 \\
206.6^{*} \\
\pm 18.6\end{array}$ & $\begin{array}{l}- \\
- \\
- \\
-\end{array}$ & $\begin{array}{c}212.9^{*} \\
\pm 25.4 \\
242.3^{*} \\
\pm 26.1 \\
245.0^{*} \\
\pm 26.2\end{array}$ & $\begin{array}{r}223.3^{*} \\
\pm 28.0 \\
211.9 \\
\pm 17.6 \\
205.8 \\
\pm 18.5\end{array}$ & $\begin{array}{c}166.3 \\
\pm 25.0 \\
198.5^{*} \\
\pm 21.9 \\
144.2 \\
\pm 14.7\end{array}$ \\
\hline $\begin{array}{l}\text { Lactate } \\
\qquad(\mathrm{mg} / 100 \mathrm{ml})\end{array}$ & Control & 15 & $\begin{array}{r}21.4 \\
\pm 1.6\end{array}$ & $\begin{array}{r}20.4 \\
\pm 1.9\end{array}$ & - & $\begin{array}{l}42.8^{*} \\
\pm 3.2\end{array}$ & $\begin{array}{r}45.5^{*} \\
\pm 3.3\end{array}$ & $\begin{array}{l}44.7^{*} \\
\pm 3.9\end{array}$ \\
\hline $\begin{array}{l}\text { Pyruvate } \\
(\mathrm{mg} / 100 \mathrm{ml})\end{array}$ & Control & 15 & $\begin{array}{r}0.86 \\
\pm 0.09\end{array}$ & $\begin{array}{r}0.90 \\
\pm 0.10\end{array}$ & - & $\begin{array}{l}1.78^{*} \\
\pm 0.12\end{array}$ & $\begin{array}{r}2.09^{*} \\
\pm 0.12\end{array}$ & $\begin{aligned} & 2.09^{*} \\
\pm & 0.15\end{aligned}$ \\
\hline
\end{tabular}

*Statistically significant as compared with control value [Pre/Et].

$\dagger$ Statistically significant as compared with control value (0).

edly to 31 per cent of control level 15 minutes after the injection of endotoxin. Thereafter hypotension around 40 to 50 per cent of control level continued in group one, as shown in Figure 1.

The cardiac output decreased to 38 per cent of control 30 minutes after the administration of endotoxin, while the methylprednisolone treated group showed a slightly increased cardiac output compared with the control group. No significant effect on mean arterial blood pressure by preadministration of steroid was detected in groups two and three (Table II and Figure 1).
10. Plasma lactic and pyruvic acid, blood glucose and haematocrit

Plasma lactic and pyruvic acid increased significantly 2-2.5 times control values following administration of endotoxin in group one, as shown in Table II and Figure 9.

Blood glucose level increased significantly to 142-145 per cent of control values 30 minutes to one hour post-endotoxin but returned to control level two hours post-endotoxin in group one, as shown in Table II and Figure 7. However, in the dexamethasone treated group it remained at a significantly high level in the same period. 
TABLE III

Effects of Dexamethasone and Methylprednisolone on Urinary Electrolytes and Osmolality During Endotoxin Shock in Dogs

\begin{tabular}{|c|c|c|c|c|c|c|}
\hline \multirow[b]{2}{*}{ Data } & \multirow[b]{2}{*}{ Group } & \multirow[b]{2}{*}{$\mathbf{N}$} & \multicolumn{4}{|c|}{ (Minutes after Et) } \\
\hline & & & 15 & 30 & 60 & 120 \\
\hline $\begin{array}{l}\text { Urine vol } \\
(\mathrm{ml} / \mathrm{kg} / \mathrm{hr})\end{array}$ & $\begin{array}{l}\text { Control } \\
\text { DMS } \\
\text { MPS }\end{array}$ & $\begin{array}{l}15 \\
12 \\
12\end{array}$ & $\begin{array}{r}1.13 \\
\pm 0.41 \\
1.23 \\
\pm 0.24 \\
1.31 \\
\pm 0.28\end{array}$ & $\begin{array}{r}0.62 \\
\pm 0.22 \\
0.62 \\
\pm 0.15 \\
0.84 \\
\pm 0.31\end{array}$ & $\begin{array}{c}0.21^{*} \\
\pm 0.03 \\
0.21^{*} \\
\pm 0.14 \\
0.44^{*} \\
\pm 0.10\end{array}$ & $\begin{aligned} & 0.13^{*} \\
& \pm 0.04 \\
& 0.13^{*} \\
& \pm 0.05 \\
& 0.31^{*} \\
& \pm 0.08\end{aligned}$ \\
\hline $\begin{array}{l}\mathrm{Na} \\
(\mathrm{mmol} / \mathrm{l})\end{array}$ & $\begin{array}{l}\text { Control } \\
\text { DMS } \\
\text { MPS }\end{array}$ & $\begin{array}{l}15 \\
12 \\
12\end{array}$ & $\begin{array}{r}108.0 \\
\pm 14.2 \\
115.5 \\
\pm 17.4 \\
114.0 \\
\pm 26.5\end{array}$ & $\begin{array}{r}110.3 \\
\pm 12.9 \\
130.6 \\
\pm 16.6 \\
103.4 \\
\pm 13.3\end{array}$ & $\begin{array}{c}100.0 \\
\pm 11.1 \\
142.1 \\
\pm 5.9 \\
70.7 \\
\pm 9.83\end{array}$ & $\begin{array}{r}87.5 \\
+16.9 \\
126.0 \\
+14.7 \\
107.0 \\
+10.8\end{array}$ \\
\hline $\mathrm{K}_{(\mathrm{mmol} / \mathrm{l})}$ & $\begin{array}{l}\text { Control } \\
\text { DMS } \\
\text { MPS }\end{array}$ & $\begin{array}{l}15 \\
12 \\
12\end{array}$ & $\begin{array}{r}125.4 \\
+16.8 \\
112.0 \\
+14.8 \\
88.7 \\
+9.0\end{array}$ & $\begin{array}{r}90.0 \\
\pm 7.4 \\
90.5 \\
\pm 11.3 \\
95.3 \\
\pm 13.7\end{array}$ & $\begin{array}{r}93.0 \\
\pm 14.2 \\
69.4 \\
+11.1 \\
84.7 \\
+11.8\end{array}$ & $\begin{array}{r}92.86 \\
\pm 14.0 \\
60.0 \\
\pm 9.7 \\
89.2 \\
\pm 14.8\end{array}$ \\
\hline$\underset{(\mathrm{mOsm} / \mathrm{l})}{\mathrm{Osm}}$ & $\begin{array}{l}\text { Control } \\
\text { DMS } \\
\text { MPS }\end{array}$ & $\begin{array}{l}15 \\
12 \\
12\end{array}$ & $\begin{array}{r}1222.8 \\
\pm 74.2 \\
1219.6 \\
\pm 114.8 \\
1146.0 \\
\pm 103.5\end{array}$ & $\begin{array}{r}937.3 \\
\pm 64.5 \\
912.9 \\
\pm 76.0 \\
1044.7 \\
\pm 159.6\end{array}$ & $\begin{array}{r}747.6 \\
+165.3 \\
910.5 \\
\pm 108.6 \\
959.1 \\
\pm 116.8\end{array}$ & $\begin{array}{r}718.6 \\
+139.5 \\
637.3 \\
+62.7 \\
575.3 \\
+130.8\end{array}$ \\
\hline
\end{tabular}

*Statistically significant as compared with control values ( $15 \mathrm{~min}$ ).

Haematocrit increased significantly to 110 and 118 per cent of control at 30 minutes and two hours respectively after the injection of endotoxin (Table V).

\section{Discussion}

Administration of endotoxin causes release of histamine and serotonin which lead to increase in capillary permeability to fluid. This induces arterial hypotension due to splanchnic pooling of blood and reduced venous return which, in turn, decreases the effective circulating blood volume. Under these conditions renal blood flow and glomerular filtration rate are markedly reduced, resulting in renal ischaemia. Furthermore, increased sympathetic tonus and release of catecholamines are evoked secondarily and these further enhance the imbalance of intra-renal blood distribution. If this state of affairs is allowed to continue for a long time, it will result in acute renal failure. In the present study we found that the mean arterial pressure fell to 39 per cent, renal cortical blood fow to $\mathbf{4 3}$ per cent and urine output to 40 per cent of control one hour after injection of endotoxin. The details of the significance and mechanisms controlling multihormonal secretion in response to haemodynamic changes during and following shock are poorly understood. One of the main purposes of our study was to elucidate the possible roles of various hormones in the above-mentioned states.

Plasma ADH concentrations increased markedly during endotoxic shock. The stimulation of hypothalamic osmoreceptors, controlled by plasma osmolality, atrial volume receptors and carotid baroreceptors, responding in turn to blood volume and arterial pressure evokes secretion of ADH from the posterior pituitary. ${ }^{9}$ These factors appeared to contribute to the increased secretion of ADH in the present study.

The 20- to 25-fold rise in plasma ADH levels, compared with pre-shock level, results not only in preservation of extracellular fluids but also in peripheral vaso-constriction. Pre-administration of methylprednisolone or dexamethasone accelerated the return of plasma ADH concentration toward pre-shock levels. This effect was substantiated by the increased urine output compared with that of the control group two hours post- 
TABLE IV

Effects of Dexamethasone and Methylprednisolone on Hematocrit, Plasma Electrolytes, Plasma Osmolality During Endotoxin Shock in Dogs

\begin{tabular}{|c|c|c|c|c|c|c|c|}
\hline \multirow[b]{2}{*}{ Data } & \multirow[b]{2}{*}{ Group } & \multirow[b]{2}{*}{$\mathbf{N}$} & \multicolumn{5}{|c|}{ (Minutes after Et) } \\
\hline & & & 0 & 15 & 30 & 60 & 120 \\
\hline $\mathrm{Ht}(\%)$ & $\begin{array}{l}\text { Control } \\
\text { DMS } \\
\text { MPS }\end{array}$ & $\begin{array}{l}15 \\
12 \\
12\end{array}$ & $\begin{array}{r}37.2 \\
\pm 1.2 \\
33.8 \\
\pm 0.9 \\
34.7 \\
\pm 1.6\end{array}$ & $\begin{array}{c}37.93 \\
\pm 1.2 \\
33.7 \\
\pm 1.4 \\
35.4 \\
\pm 0.9\end{array}$ & $\begin{array}{c}40.93 \\
\pm 1.4 \\
36.1 \\
\pm 1.4 \\
38.6 \\
\pm 1.6\end{array}$ & $\begin{array}{r}42.3 \\
\pm 1.5 \\
36.7 \\
\pm 2.1 \\
40.8 \\
\pm 1.7\end{array}$ & $\begin{array}{r}43.0 \\
\pm 1.4 \\
39.3 \\
\pm 2.3 \\
41.4 \\
\pm 2.3\end{array}$ \\
\hline $\begin{array}{r}\text { Plasma Na } \\
(\mathrm{mmol} / \mathrm{l})\end{array}$ & $\begin{array}{l}\text { Control } \\
\text { DMS } \\
\text { MPS }\end{array}$ & $\begin{array}{l}15 \\
12 \\
12\end{array}$ & $\begin{array}{l}139.6 \\
\pm 1.0 \\
137.3 \\
\pm 1.2 \\
137.1 \\
\pm 0.7\end{array}$ & $\begin{array}{l}139.7 \\
\pm 0.9 \\
138.8 \\
\pm 1.3 \\
136.3 \\
\pm 1.1\end{array}$ & $\begin{array}{l}137.5 \\
\pm 0.5 \\
137.4 \\
\pm 1.0 \\
137.4 \\
\pm 0.7\end{array}$ & $\begin{array}{l}136.7 \\
\pm 1.5 \\
136.7 \\
\pm 1.0 \\
138.0 \\
\pm 0.5\end{array}$ & $\begin{array}{l}139.5 \\
\pm 1.1 \\
137.7 \\
\pm 1.0 \\
138.1 \\
\pm 0.6\end{array}$ \\
\hline $\mathrm{K}_{(\mathrm{mmol} / \mathrm{l})}$ & $\begin{array}{l}\text { Control } \\
\text { DMS } \\
\text { MPS }\end{array}$ & $\begin{array}{l}15 \\
12 \\
12\end{array}$ & $\begin{array}{r}3.27 \\
\pm 0.10 \\
3.03 \\
\pm 0.08 \\
2.83 \\
\pm 0.07\end{array}$ & $\begin{array}{r}3.10 \\
\pm 0.10 \\
2.86 \\
\pm 0.12 \\
2.88 \\
\pm 0.11\end{array}$ & $\begin{aligned} & 3.30 \\
& \pm 0.12 \\
& 2.90 \\
& \pm 0.11 \\
& 2.32 * \\
& \pm 0.09\end{aligned}$ & $\begin{array}{c}2.85^{*} \\
\pm 0.12 \\
2.59^{*} \\
\pm 0.11 \\
2.26^{*} \\
\pm 0.10\end{array}$ & $\begin{aligned} & 2.86^{*} \\
& \pm 0.07 \\
& 2.62^{*} \\
& \pm 0.12 \\
& 2.63^{*} \\
& \pm 0.10\end{aligned}$ \\
\hline $\begin{array}{l}\text { Osm } \\
(\mathrm{mOsm} / \mathrm{L})\end{array}$ & $\begin{array}{l}\text { Control } \\
\text { DMS } \\
\text { MPS }\end{array}$ & $\begin{array}{l}15 \\
12 \\
12\end{array}$ & $\begin{array}{l}288.0 \\
\pm 1.6 \\
290.2 \\
\pm 2.8 \\
288.2 \\
\pm 1.6\end{array}$ & $\begin{array}{r}286.7 \\
\pm 1.8 \\
289.4 \\
\pm 3.2 \\
290.3 \\
\pm 1.1\end{array}$ & $\begin{array}{l}291.0 \\
\pm 2.1 \\
293.6 \\
\pm 2.6 \\
291.3 \\
\pm 1.9\end{array}$ & $\begin{array}{r}290.2 \\
\pm 1.8 \\
291.7 \\
\pm 2.5 \\
291.1 \\
\pm 1.3\end{array}$ & $\begin{array}{l}299.5^{*} \\
\pm 2.18 \\
291.9 \\
\pm 2.6 \\
288.7 \\
\pm 1.2\end{array}$ \\
\hline
\end{tabular}

*Statistically significant as compared with control values.

endotoxin and was especially evident in the methylprednisolone pre-treated group two.

Methylprednisolone $30 \mathrm{mg} / \mathrm{kg}$ was more effective than dexamethasone $5 \mathrm{mg} / \mathrm{kg}$ in reducing ADH levels. This difference did not appear to be qualitative but rather quantitative and due to the dose of steroid. For instance, Vargish ${ }^{10}$ has reported that in animal experiments dexamethasone $15 \mathrm{mg} / \mathrm{kg}$ is superior to methylprednisolone $31 \mathrm{mg} / \mathrm{kg}$ in improving the mortality in endotoxin shock.

The depressive effect of steroids on plasma concentrations of ADH during haemorrhagic shock was reported by Oyama, et al.' It is interesting to note that methylprednisolone 30 $\mathrm{mg} / \mathrm{kg}$ reduced the plasma concentration of ACTH in dogs. The mechanism for this could be negative feedback during shock activated by the administration of steroids, as speculated by Yates, et al." ACTH is influenced by the hypothalamic corticotropin releasing factor; besides, some similarity exists between ADH and corticotropin releasing factor. Recently Stillman, et $a .^{12}$ found that the administration of dexamethasone depressed the rise of $\mathrm{ADH}$ secretion in the adrenalectomized rat. Therefore, it could be speculated that our observation of reduced $\mathrm{ADH}$ levels in the steroid treated groups are due to the decreased level of ACTH induced by the steroids.

Plasma renin activity represents angiotensin II, which is a potent vasoconstrictor as well as a stimulator of the synthesis and secretion of aldosterone. Secretion of renin from the juxtaglomerular apparatus is stimulated (i) by renal afferent arteriolar baroreceptors which are sensitive to hypotension, (ii) by chemoreceptors located in the renal tubular macula densa which is sensitive to plasma sodium concentration, and (iii) by increased sympathetic tonus. These three factors appeared to contribute in the present study to the two-fold increase in plasma renin activity during shock. Administration of steroids inhibited the increase in plasma renin activity. This implies that steroid might induce mild vasodilation of the peripheral circulation by reducing secretion of both ADH and angiotensin.

Aldosterone enhances tubular sodium and chloride reabsorption and increases secretion of potassium and hydrogen ions. Thus aldosterone 
TABLE $V$

Effects of Dexamethasone and Methylprednisolone on ACjd-Base Balance DuRING ENDOTOXIN SHOCK IN DOGS

\begin{tabular}{|c|c|c|c|c|c|c|c|}
\hline \multirow[b]{2}{*}{ Data } & \multirow[b]{2}{*}{ Group } & \multirow[b]{2}{*}{$\mathbf{N}$} & \multicolumn{5}{|c|}{ (Minutes after Et) } \\
\hline & & & 0 & 15 & 30 & 60 & 120 \\
\hline $\mathrm{pH}$ & $\begin{array}{l}\text { Control } \\
\text { DMS } \\
\text { MPS }\end{array}$ & $\begin{array}{l}15 \\
12 \\
12\end{array}$ & $\begin{array}{r}7.35 \\
+0.01 \\
7.38 \\
+0.03 \\
7.36 \\
\pm 0.03\end{array}$ & $\begin{array}{r}7.27 \\
\pm 0.01 \\
7.42 \\
\pm 0.01 \\
7.34 \\
\pm 0.04\end{array}$ & $\begin{aligned} & 7.22^{*} \\
& \pm 0.02 \\
& 7.26^{*} \\
& \pm 0.02 \\
& 7.25^{*} \\
& \pm 0.02\end{aligned}$ & $\begin{array}{c}7.22^{*} \\
\pm 0.02 \\
7.24^{*} \\
\pm 0.02 \\
7.20^{*} \\
\pm 0.02\end{array}$ & $\begin{array}{r}7.20^{*} \\
\pm 0.03 \\
7.23^{*} \\
\pm 0.02 \\
7.22^{*} \\
\pm 0.02\end{array}$ \\
\hline $\begin{array}{l}\mathrm{Pa}_{\mathrm{O}_{2}} \\
\quad \text { (torr) }\end{array}$ & $\begin{array}{l}\text { Control } \\
\text { DMS } \\
\text { MPS }\end{array}$ & $\begin{array}{l}15 \\
12 \\
12\end{array}$ & $\begin{array}{r}110.3 \\
\pm 5.2 \\
111.7 \\
\pm 3.0 \\
109.7 \\
\pm 5.9\end{array}$ & $\begin{array}{l}117.8 \\
\pm 4.4 \\
110.5 \\
\pm 3.1 \\
117.7 \\
\pm 6.4\end{array}$ & $\begin{array}{r}108.7 \\
\pm 5.9 \\
100.6 \\
\pm 5.4 \\
113.2 \\
\pm 5.9\end{array}$ & $\begin{array}{r}111.7 \\
\pm 6.2 \\
101.0 \\
\pm 4.0 \\
115.8 \\
\pm 5.2\end{array}$ & $\begin{array}{r}105.9 \\
\pm 6.1 \\
107.5 \\
\pm 4.2 \\
117.3 \\
\pm 16.2\end{array}$ \\
\hline $\begin{array}{l}\mathrm{PaCO}_{2} \\
\text { (torr) }\end{array}$ & $\begin{array}{l}\text { Control } \\
\text { DMS } \\
\text { MPS }\end{array}$ & $\begin{array}{l}15 \\
12 \\
12\end{array}$ & $\begin{array}{r}40.9 \\
\pm 1.7 \\
36.0 \\
\pm 0.5 \\
37.6 \\
\pm 1.8\end{array}$ & $\begin{array}{r}38.3 \\
\pm 1.5 \\
34.0 \\
\pm 1.7 \\
30.9 \\
\pm 3.2\end{array}$ & $\begin{array}{r}35.9 \\
\pm 1.6 \\
35.2 \\
\pm 1.9 \\
34.9 \\
\pm 1.5\end{array}$ & $\begin{array}{r}37.2 \\
\pm 2.1 \\
36.2 \\
+2.0 \\
34.9 \\
\pm 1.3\end{array}$ & $\begin{array}{r}35.3 \\
\pm 1.9 \\
33.9 \\
\pm 1.9 \\
33.8 \\
\pm 1.2\end{array}$ \\
\hline $\begin{array}{l}\text { B.E. } \\
\qquad(\mathrm{mmol} / \mathrm{l})\end{array}$ & $\begin{array}{l}\text { Control } \\
\text { DMS } \\
\text { MPS }\end{array}$ & $\begin{array}{l}15 \\
12 \\
12\end{array}$ & $\begin{array}{l}-3.5 \\
\pm 0.7 \\
-1.3 \\
\pm 0.7 \\
-1.9 \\
\pm 0.7\end{array}$ & $\begin{array}{l}-2.9 \\
\pm 0.7 \\
-1.3 \\
\pm 0.7 \\
-2.2 \\
\pm 0.7\end{array}$ & $\begin{array}{c}-10.0^{*} \\
\pm 0.8^{*} \\
-11.1^{*} \\
\pm 1.2^{*} \\
-11.7^{*} \\
\pm 0.7\end{array}$ & $\begin{array}{c}-12.0^{*} \\
\pm 0.9 \\
-11.4^{*} \\
\pm 1.0 \\
-12.4^{*} \\
\pm 1.4\end{array}$ & $\begin{array}{c}-11.5^{*} \\
\pm 1.2 \\
-13.7^{*} \\
\pm 0.9 \\
-14.2^{*} \\
\pm 0.8\end{array}$ \\
\hline
\end{tabular}

Every figures noted as mean \pm S.E

- Statistically significant as compared with control values.

indirectly promotes the renal tubular reabsorption of water and so conserves the intravascular volume and maintains the blood pressure as one of the defense mechanisms against stress. However, excessive secretion of aldosterone can induce oedema and hypertension. Steroids depress plasma renin activity but have no significant influence on the plasma concentration of aldosterone. This dissociation of plasma renin activity from aldosterone could be explained by the following postulate: As discussed above, angiotension has two activities, namely vasoconstriction and synthesis of aldosterone. In shock, the former activity might be stronger than the latter. Furthermore, not only the increase in renin activity, but also the secretion of $\mathrm{ACTH}$, the release of catecholamine and acute acidosis induce secretion of aldosterone. Beyond that it is possible that the adrenalcortex mayexhibitdecreased sensitivity to angiotensin during shock. Combination of all these factors could modify the plasma concentration of aldosterone during endotoxin shock.
The increased plasma concentrations of catecholamine during and following endotoxic shock were similar to those observed in haemorrhagic shock and reported by Oyama, et al. ${ }^{1}$ This catecholamine increase would contribute to the tendency of metabolic acidosis. Although in the present study we did not investigate the effect of steroids on the plasma concentration of catecholamine, the present authors have found that plasma levels of catecholamines were reduced during and following haemorrhagic shock.

Elevations of plasma cortisol levels were observed during endotoxin shock. Similar findings were reported by Cavanagh ${ }^{13}$ in primates in endotoxic shock and by us' in haemorrhagic shock in dogs. Plasma concentrations of cortisol were significantly higher in the methylprednisolone group than in the other two groups. Administration of methylprednisolone interferes with plasma cortisol level to the extent of 20 to 30 per cent, and this could account for our results.

Factors contributing to the reduced urine out- 


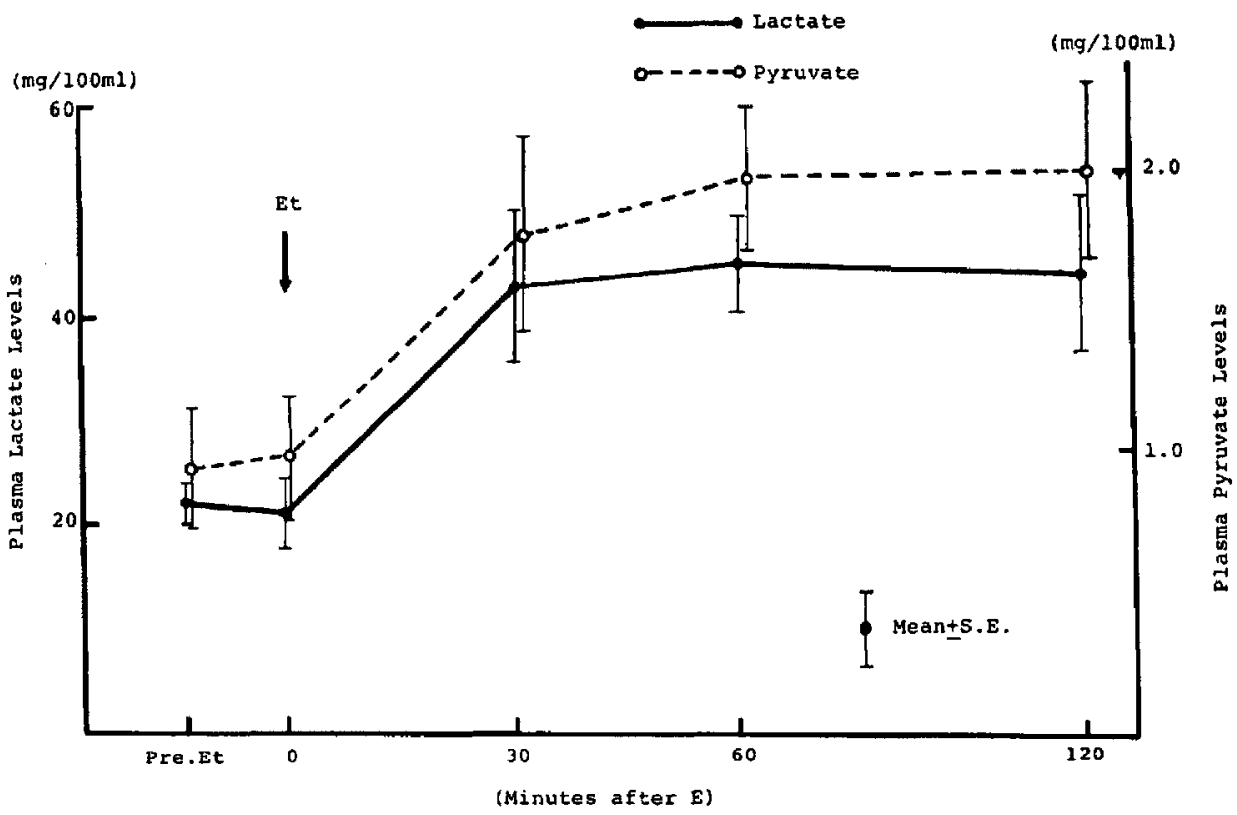

FIGURE 9. Effects of endotoxin shock on plasma levels of lactic acid and pyruvic acid in dogs.

put during shock are explained by the decrease in both cardiac output and renal blood flow, by increased secretion of both ADH and catecholamine and by the enhanced activity of the reninangiotensin-aldosterone system. Plasma osmolality correlated with plasma ADH concentration during shock. Administration of methylprednisolone induced a two-fold increase of urinary output and also increased cardiac output slightly, as compared with controls. Inhibition of $\mathrm{ADH}$ release by methylprednisolone could account for the augmented urinary output.

The mechanism of reduced renal sodium output during shock can be explained by the following factors: (i) shift of sodium from extracellular fluid at large to its interstitial component, (ii) increased secretion of aldosterone resulting in reduced urinary output of sodium, and (iii) loss of sodium into the so-called "third space". Although the details of the mechanisms are unknown, increased secretion of aldosterone and haemodilution through the administration of lactated Ringer's solution could contribute to the decreased plasma concentration of potassium during shock.

Urine osmolality decreased markedly to 50 per cent of control during shock, which implies a reduction in the renal capacity to concentrate urine. The following factors may be responsible: (i) reduction in the amount of sodium supplied to Henle's loop, (ii) damage to the renal concentrating mechanism, (iii) the preservation of renal medullary blood flow despite the marked fali in cortical perfusion, so that medullary sodium is washed out adequately even during shock and, finally, (iv) decreased sensitivity of the collection tubules to ADH.

Increased plasma concentrations of lactic acid and pyruvate during endotoxic shock suggest anerobic glycolysis due to reduced peripheral perfusion and hypoxia with resultant metabolic acidosis. It is interesting to note that the administration of steroid increased blood plasma $\mathrm{pH}$ slightly during endotoxic shock.

The mechanism of the shock-protecting effect of steroids is not clearly known, although several hypotheses have been advanced. ${ }^{14-17}$ They include enhancement of cardiac output or potentiation of the sympathomimetic actions of norepinephrine, antagonism to histamine, vasodilatation related to $\alpha$-adrenergic receptor blockade, the protection of lysosomal membranes and reduction of myocardial depression. ${ }^{14-17}$ However, the role of steroid in reducing the secretion of $\mathrm{ADH}$ and of the renin-angiotensin-aldosterone system has never been elucidated. We speculate 
that the administration of fluid, blood and antibiotics alone would not be adequate treatment of endotoxic shock if the increased release of ADH, catecholamine and over-activity of reninangiotensin-aldosterone system were to continue for a long period. Administration of steroids in the early stages of shock is beneficial by improving peripheral perfusion because they prevent the over-secretion of these hormones.

\section{SUMMARY}

The effect of endotoxic shock on endocrine function and the anti-shock effects of dexamethasone and methylprednisolone were investigated in 44 mongrel dogs. Plasma concentrations of antidiuretic hormone (ADH), adrenocorticotropic hormone (ACTH), epinephrine, norepinephrine, aldosterone, plasma renin activity, cortisol, and insulin were measured simultaneously during and following endotoxic hypotension. Other parameters, such as cardiac output, renal tissue plasma flow, mean arterial blood pressure, urine volume and osmolality, serum and urine electrolytes, blood gas analysis, blood glucose, lactate and pyruvate concentrations were also determined simultaneously during the procedure. Dogs anaesthetized with pentobarbitone were given a fatal intravenous dose of $\mathrm{E}$. coli (Difco) $3 \mathrm{mg}$ per $\mathrm{kg}$ body weight. Lactated Ringer's solution $6 \mathrm{ml} / \mathrm{kg} / \mathrm{hr}$ was given throughout the procedure. Methylprednisolone $30 \mathrm{mg} / \mathrm{kg}$ or dexamethasone $5 \mathrm{mg} / \mathrm{kg}$ was administered just prior to the administration of the endotoxin.

Plasma ADH concentrations were found to be increased 20 and 25 times at 15 and 30 minutes post-endotoxin, respectively. Plasma levels of epinephrine and norepinephrine, aldosterone, plasma renin activity, cortisol and insulin increased significantly to $21,4,4,2,3$ and 5 times, respectively, 30 minutes post-endotoxin, but thereafter they decreased gradually. Renal cortical tissue blood flow decreased to a low level about 39-42 per cent of control 15 minutes postendotoxin in all groups. Urine volume, osmolality, as well as sodium and potassium concentrations decreased significantly in the postendotoxin period. Mean arterial blood pressure and cardiac output, blood $\mathrm{pH}$ and base excess fell significantly following administration of the endotoxin. Plasma lactic and pyruvic acid, blood glucose and haematocrit increased significantly during the same period.
Methylprednisolone (MP) $30 \mathrm{mg} / \mathrm{kg}$ or dexamethasone $5 \mathrm{mg} / \mathrm{kg}$ administered intravenously before the endotoxin caused a significant decrease of the plasma levels of $\mathrm{ADH}$, aldosterone and ACTH as compared with the control group which had received no steroids. No significant effect of steroid was observed in renal tissue blood flow or mean arterial blood pressure. Administration of methylprednisolone before the endotoxin improved urine output significantly, but affected elevation in blood $\mathrm{pH}$ and cardiac output only to an inșignificant degree. Our data suggest that the administration of methylprednisolone or dexamethasone is beneficial in improving endotoxic shock by decreasing the plasma levels of vasoactive hormones such as $A D H$ and the renin-angiotensin-aldosterone system.

\section{RÉSUMÉ}

Le retentissement du choc endotoxique sur la fonction endocrine et les effets anti-choc de la déxaméthasone et de la méthylprednisolone ont été étudiés sur 44 chiens bâtards. La concentration plasmatique de l'hormone antidiurétique (ADH), de l'hormone corticotrope (ACTH), de l'épinéphrine, de la norépinéphrine, de l'aldostérone, l'activité de la rénine plasmatique, du cortisol et de l'insuline furent mesurées simultanément pendant et après l'hypotension obtenue par une endotoxine. D'autres paramètres tels que le débit cardiaque, le flux plasmatique rénal, la pression artérielle moyenne, le volume et l'osmolarité urinaires, les électrolytes sériques et urinaires, les gaz du sang, la glycémie, la concentration des acides lactique et pyruvique furent aussi mesurés au cours de cette étude. Des chiens anesthésiés au pentobarbitone ont reçu une dose intraveineuse léthale de colibacilles (Difco) à la dose de $3 \mathrm{mg} / \mathrm{kg}$. Une solution de lactate Ringer fut perfusée continuellement à la vitesse de 6 $\mathrm{ml} / \mathrm{kg} / \mathrm{hre}$ pendant l'étude. De la méthylpredminisolone $30 \mathrm{mg} / \mathrm{kg}$ et de la déxaméthasone 5 $\mathrm{mg} / \mathrm{kg}$. furent injectées immédiatement avant l'endotoxine

La concentration plasmatique d'ADH a augmenté à 20 fois et à 25 fois le contrôle à la quinzième et à la trentième minute suivant l'injection d'endotoxine. Une augmentation significative a été notée pour les niveaux plasmatiques de l'épinéphrine (2l fois), de la norépinéphrine (4 fois), de l'aldostérone (4 fois), pour l'activité de la rénine plasmatique ( 2 fois), du cortisol ( 3 fois) et de l'insuline (5 fois) 30 minutes après l'injection 
de l'endotoxine. Cette augmentation a été suivie d'une baisse progressive. Le flux sanguin du cortex rénal a diminué à un niveau ausși bas que 39 à 42 pour cent du contrôle 15 minutes après l'injection d'endotoxine dans tous les cas. Le volume et l'osmolarité urinaire ainsi que les concentrations en sodium et en potassium ont diminué de façon significative dans la période qui suivait l'endotoxine. La pression artérielle moyenne et le débit cardiaque, le $\mathrm{pH}$ sanguin et l'excès de bases ont diminué de façon significative après l'administration de l'endotoxine. Pendant la même période, les acides lactique et pyruvique, la glycémie et l'hématocrite ont accusé une hausse significative.

La méthylprednisolone (MP) $30 \mathrm{mg} / \mathrm{kg}$ et la déxaméthasone $5 \mathrm{mg} / \mathrm{kg}$ administrées par la voie intraveineuse avant l'endotoxine ont produit une baisse significative du niveau plasmatique de l'ADH, de l'aldostérone et de l'ACTH en comparaison du groupe contrôle n'ayant pas reçu de stéroides. Ceux-ci n'ont pas eu d'effets significatifs sur le flux rénal et la pression artérielle moyenne. L'administration de méthylprednisolone avant l'endotoxine a produit une amélioration significative du débit urinaire sans élévation importante du pH sanguin et du débit cardiaque. Nos données nous permettent de croire que l'administration de méthylprednisolone ou de déxaméthasone peut s'avérer bénéfique dans le choc endotoxique en augmentant la sécrétion d'hormones vasoactives telles que l'ADH et l'activité du système rénine-angiotensinealdostérone.

\section{REFERENCES}

1. Orama, T., Matsuki, A., Kudo, T., Kudo, M., Yamashita, M., \& IshiHARA, $H$. Effect of corticosteroids on endocrine function in haemorrhagic shock. Canad. Anaesth. Soc. J. 25: 7 (1978).

2. LeightoN, K. \& BRUCE, C. Distribution of kidney blood flow: a comparison of methoxyflurane and halothane effects as measured by heated thermocouple. Canad. Anaesth. Soc. J. 22: 125 (1975).

3. Husain, M.K. Fernando, N., Shapiro, M. KAGAN, A., \& GLICK, S.M. Radioimmunoassay of arginine vasopressin in human plasma. J. Clin. Endocrinol Metab. 37: 616(1973).

4. Griffiths, J.C., Lenng, F.Y.T. \& McDonald, T.J. Fluorimetric determination of plasma cathecolamines: normal human epinephrine and norepinephrine levels. Clin. Chem. Acta 30:395 (1970).

5. McKenzie, J.K. \& Clements, J.A. Simplified radioimmunoassay for serum aldosterone utilizing increased specificity. J. Clin. Endocrinol. Metab. 38: 622 (1974).

6. Morgan, C.R. \& Lazarow, A. Immunoassay of insulin, two antibody system. Diabetes 12: 115 (1963),

7. RUDd, B.T., SAMPSON, P., \& BRoOKE, B.N. A new fluorimetric method of plasma cortisol assay with a study of pituitary-adrenal function using metyrapone. Endocrinology 27: 317 (1963).

8. AUthoY, G.H. \& SidNeY, V.R. The enzymatic assay of pyruvic and lactic acids: a definite procedure. Clinica Chimica Acta 19: 357 (1968).

9. Kurzman, N.A. \& Boonjarern, S. Physiology of antidiuretic hormone and the interrelationship between the hormone and the kidney. Nephron 15: 167 (1975).

10. VARGish, T., TuRner, C.H., \& Bond, R.F. Dose response relationships in steroid therapy for hemorrhagic shock. Ann, Surg. 43: 30 (1977).

11. Yates, F.E., Russell, S.M., Dal.l.MAN, M.F., Hedge, G.A., Mccann, S.M., \& Dhariwal, A.P.S. Potentiation by vasopression of corticotropin release induced by corticotropin-releasing factor. Endocrinol. 88: 3 (1971).

12. Stillman, M.A., Recht, L.D. Rosario, S.L. Seif, S.M., Robinson, A.G., \& Zimmerman, E.A. The effects of adrenalectomy and glucocorticoid replacement of vasopressin and vasopressin-neurophysin in the Zona externa of the median eminence of the rat. Endocrinol. 101:42 (1977).

13. CaVANaGH, D. \& RAO, P.S. The pathophysiology of endotoxin shock in the primate. Amer. J. Obstet. Gynec. 108: 705 (1970).

14. LEFER, A.M. \& VerRIERS, R.L. Role of corticosteroids in the treatment of circulatory collapse states. Clin. Pharmacol. Ther. 1l:630 (1970).

15. Altura, B.M. \& Altura, B.T. Peripheral vascular actions of glucocorticoids and their relationship to protection in circulatory shock. J. Pharma. Exp. Therap. 190: 300 (1974).

16. GleNN, T.M. \& LAFEW, A.M. Anti-toxic action of methylprednisolone in hemorrhagic shock. Europ. J. Pharmacol. 13: 230 (1971)

17. Clermont, H.G., Williams, J.S., \& Adams, J.T. Steroid effect on the release of the lysosomal enzyme acid phosphatase in shock. Ann. Surg. 179: 917 (1974). 